\title{
PREVENTIVE ACTIVITY OF BODIES OF THE NATIONAL POLICE OF UKRAINE IN THE AREA OF THE UNITED FORCES OPERATIONS
}

\begin{abstract}
Abroskin V. V.
INTRODUCTION

The Constitution of Ukraine defines the protection of the state sovereignty of Ukraine, territorial integrity, inviolability of the state border as one of the most important functions of the state at the present stage ${ }^{1}$.

In 2014, the Russian Federation launched an armed aggression against Ukraine, which resulted in the illegal occupation of the Autonomous Republic of Crimea $^{2}$, carrying out armed invasion into the territory of Donetsk and Luhansk regions ${ }^{3}$. Armed conflicts become more intense, so the united forces operations in Donetsk and Luhansk regions influenced the need to study approaches to resolving armed conflict within the state.

The security vector is identified as one of the key vectors of the development of our country, in accordance with the Strategy of Sustainable Development "Ukraine-2020", that should provide ensuring the security of the state, business and citizens ${ }^{4}$. Our state is tasked with becoming a state capable of protecting its borders and ensuring public security not only in its territory but also in the European region. In turn, this task requires adjusting the tasks and functions of the police, introducing new criteria for evaluating police performance.

Today, the National Police of Ukraine is a universal system of structural units, which are entrusted with important functions to ensure law and order in the state, protection of the population. In the territory of modern Ukraine there is a new, reformed system of bodies of the National Police of Ukraine, which actively borrows the best international practices in order to optimize its own
\end{abstract}

1 Василенко В. А. Російсько-українська війна 2014 року: причини, перебіг та політико-правові оцінки. Украӥнський тиждень. 2014. № 42. С. 28-42.

2 Про Стратегію сталого розвитку “Україна - 2020": Указ Президента України від 12 січ. 2015 p. № 5/2015. URL: http://zakon2.rada.gov.ua/laws/show/5/2015 (дата звернення 15.10.2019).

3 Про Стратегію сталого розвитку “Україна - 2020": Указ Президента України від 12 січ. 2015 р. № 5/2015. URL: http://zakon2.rada.gov.ua/laws/show/5/2015 (дата звернення 15.10.2019).

4 Про Стратегію сталого розвитку “Україна-2020": Указ Президента України від 12 січ. 2015 p. № 5/2015. URL: http://zakon2.rada.gov.ua/laws/show/5/2015 (дата звернення 15.10.2019). 
activities. One of the such practice is to change the work vector of these bodies by transforming them from punitive to preventive, and in some cases - to service agencies. This is due primarily to the fact that the main value for many states is directly human today, since the suppression of rigid coercive measures is gradually being replaced by the development and implementation of preventive measuresThe implementation of these measures by the police is, first of all, an important guarantee of respect for human rights and freedoms; secondly, it increases the level of legal consciousness in society; thirdly, it significantly increases the level of public trust in law enforcement, which has a positive impact on the state of law and order in the country. Необхідність здійснення превентивних заходів The need for preventive measures by the police is confirmed by the number of detected administrative offenses, in particular - in 2016 - 1 million 656 thousand, 2017 - 2 million 845 thousand, $2018-3$ million 639 thousand 5 .

The activities of the police directed at reducing the number of criminal, administrative and other offenses, and it is not enough to stop unlawful acts, every effort should be made to prevent them from committing at all.

The theoretical basis of the study are works of Ukrainian scientists on the study of certain aspects of law enforcement and, in particular, the legal regulation of the activities of police in the field of public security, namely: V. Averyanova, S. Alfiorova, O. Andriyko, O. Bandurki, O. Bezpalova, Y. Bityaka, V. Galunko, V. Garashchuk, O. Hetmanets, I. Golosnichenko, N. Grishina, S. Gusarova, O. Jafarova, O. Klyueva, T. Kolomoets, V. Kolpakova, A. Komzyuka, O. Kuzmenko, K. Levchenko, O. Nikolenko, O. Muzychuk, O. Sinyavskaya, V. Sokurenko, S. Stetsenko and others.

An in-depth study of the preventive activity of the police in armed conflicts within the state not only makes it possible to improve the efficiency and effectiveness of administrative activity in the context of emergency administrative and legal regimes, but also allows to determine the optimal measures for their settlement. At present, the issue of preventive activity by the police during the united forces operation remains an issue in view of the lack of research of scientific developments in this field.

\section{Methodological approaches \\ about understanding preventive police activity}

The Constitution of Ukraine declared that a person, his life and health, honor and dignity, integrity and security are recognized in Ukraine as the

5 Адміністративні правопорушення: демографічна та соціальна статистика. Правосуддя та злочинність. Державна служба статистика Украйни: веб-сайт. URL: http://www.ukrstat.gov.ua (дата звернення: 15.10.2019). 
highest social value ${ }^{6}$. For the purpose of practical implementation of the above constitutional requirements, the relevant law enforcement agencies are functioning in our country, among which are the bodies of the National Police of Ukraine. They are the ones responsible for fulfilling the task of carrying out preventive activities.

According to paragraphs 1, 2 and 3 of Part 1 of Art. 23 ("Basic powers of the police") of the Law of Ukraine "About the National Police" the police in accordance with the tasks assigned to it: "carry out preventive activities aimed at preventing the commission of offenses; identifies the causes and conditions conducive to the commission of criminal and administrative offenses, and takes measures within their competence to eliminate them; takes measures to detect criminal and administrative offenses, as well as suspends detected criminal and administrative offenses"

Preventive police activity is aimed at preventing offenses that could potentially be committed by a person or a group of people, and is a complex of legal, organizational and psychological measures that together allow to prevent committing offenses.

For a full research, first of all, should refer to the definition of "preventive", that means "that prevents something". In turn, preventive police activity is a complex of actions (measures) implemented by police officers for the purpose of preventing an offense. This is to some extent reflected in the doctrinal definitions of the concept of "preventive police activity", about which there is no unambiguous understanding, and there is no definition of the object of its purpose - offense, misdemeanor or crime.

For example, I. Volokitenko proposes the author's definition of the concept of "preventive activity" as "a special type of activity of police officers who in their work prevent committing offenses in the public order"9. This concept is explained in details by R. Valeev and D. Churikov, understanding it as "a component of combating crime, and identifying special prevention aimed at preventing crimes by specific people, and general prevention aimed at preventing crime by an indeterminate number of

${ }^{6}$ Конституція України : Закон України від 28 черв. 1996 р. № 254к/96-BP. URL: http://zakon.rada.gov.ua/laws/show/254к/96-BР (дата звернення: 03.10.2019).

${ }^{7}$ Про Національну поліцію : Закон України від 02 липн. 2015 р. № 580-VIII. URL: https://zakon.rada.gov.ua/laws/show/580-19 (дата звернення: 15.10.2019).

${ }^{8}$ Словник української мови : в 11 т./ голова редкол. І. К. Білодід. Київ : Наукова думка, 1976. Т. 7.724 с.

9 Волокітенко I. О. Адміністративно-правовий статус підрозділів превентивної діяльності Національної поліції України. Visegrad Journalon Human Rights. 2016. № 6. Ч. 2. C. 42-46. 
people. At the same time, the objects of prevention, in addition to people, are criminogenic determinants of crime" 10 .

The content of preventive activity can be submitted from the understanding of measures by which it is implemented. N. Didik notes that "in law preventive measures are called preventive and other measures aimed at preventing criminal offenses and other offenses. In legal science, distinguish such types of prevention as general prevention - preventing the commission of offenses by other people. It is the prevention of committing criminal offenses by citizens prone to wrongdoing; private prevention means the prevention of committing new criminal offenses by people who have already committed any offenses"11.

The ambiguity of understanding of the correlation of the above concepts is noticed by $\mathrm{O}$. Batrachenko, who defines forms of preventive activity of the National Police: "identify the causes and conditions that contribute to the commission of administrative offenses that encroaching on public safety and the procedure for taking measures within their competence to eliminate them; monitoring the causes and conditions that contributed to the commission of administrative offenses that violate public safety and order; determination of the state of public security and order in the state or in a specific territory; developing measures to maintain and enhance public safety and order; monitoring of the operational situation in the country; study, analysis and generalization of results and effectiveness of police activity; informing in the manner and manner prescribed by law the relevant state bodies; round-the-clock patrolling of the service area to ensure proper public order, public safety and traffic enforcement; taking measures aimed at eliminating threats to the life and health of individuals and public safety resulting from the commission of an administrative offense that violates public safety and order; taking measures to prevent and end domestic violence; demands from citizens to observe public order and from persons who violate public order, termination of offenses" ${ }^{\prime 2}$.

In this manner, it can be concluded that the concepts of preventive and preventive activities are not differentiated in the scientific community.

${ }^{10}$ Валєєв Р. Г., Чуріков Д. С. Превентивна діяльність поліцейських як стадія протидії злочинності. Актуальні питання протидї злочинності в сучасних умовах: вітчизняний та зарубіжний досвід : матеріали II Міжнар. наук.-практ. конф., 15 бер. 2013 р. Дніпро : Дніпропетр. держ. ун-т внутр. справ, 2018. С. 212-215.

${ }^{11}$ Дідик Н. І. Превентивні функції в діяльності патрульної поліції. Вісник Луганського державного університету внутрімніх справ імені Е. О. Дідоренка. 2016. Вип. 2. C. $188-194$.

${ }^{12}$ Батраченко О. В. Форми правоохоронної діяльності національної поліції щодо забезпечення публічної безпеки та порядку в державі. Форум права. 2016. № 2. С. 5-10. URL: http://nbuv.gov.ua/j-pdf/FP_index.htm_2016_2_3. (дата звернення: 15.10.2019). 
However, the legislator, in Art. 23 of the Law of Ukraine "On the National Police" specifies that the police carry out preventive activities aimed at preventing offenses and set out in Art. 31 preventive police measures, which include: 1) verification of identity documents; 2) interviewing a person; 3) surface inspection and inspection; 4) stopping the vehicle; 5) the requirement to leave space and restrict access to the designated area; 6) restriction of movement of the person, vehicle or actual possession of the thing; 7) penetration into the dwelling or other possession of a person; 8 ) verification of compliance with the requirements of the permit system of law enforcement agencies; 9) the use of technical instruments and equipment having the functions of photo and film, video recording, photo and film means, video; 10) verification of compliance with the statutory restrictions on persons under administrative supervision and other categories of persons; 11) police care ${ }^{13}$.

Because of the plurality of terms, that used by the legislator, the content and relation of concepts remain unclear: "prevention", "termination" remain unclear. The concept of "prevention" in the disclosure of its essence is almost identical with the activity aimed at preventing offenses, but prevention is aimed at it. It is most often used in the context of prevention of offenses - "a complex multilevel system of bodies, organizations, institutions that influence social objects in order to prevent possible violations of legal prohibitions and eliminate the factors that cause them"14.

If "prevention" can be used as common in their meaning, termination of the offense will occur in case of unlawful intent in the person directly during its commission. Prevention has a more specific effect on the subject of "preventing something unpleasant, unwanted"15, a Prevention has a more specific impact because it implies "preventing or preventing something unpleasant, unwanted", so it can take place both as a preventative, preventive measure (more generally, to carry out general preventive measures aimed at preventing certain categories of offenses) and during the termination of the offense. In this manner, Prevention of the offense is most often carried out at the stages of detecting the intention or preparation for the offense, and less often during the prevention of its commission. The termination of the offense can only take place if the unlawful activity has already begun.

${ }^{13}$ Про Національну поліцію : Закон України від 02 липн. 2015 р. № 580-VIII. URL: https://zakon.rada.gov.ua/laws/show/580-19 (дата звернення: 15.10.2019).

${ }_{14}$ Макаренко О. М. Суб’єкти профілактики правопорушень. Право і Безпека. 2004. № 3 (3). С. $68-70$.

${ }^{15}$ Словник української мови : в 11 т. / голова редкол. І. К. Білодід. Київ : Наукова думка, 1976. Т. 7.724 с. 
In this case, the main task is to minimize or prevent the adverse effects of the offense. Prevention is carried out regardless of any particular offense, and is aimed at improving the criminogenic situation in the state and its individual regions.

Considering that the preventive activities carried out by the National Police may include the prevention of offenses, we consider it necessary to briefly outline the content of the latter ${ }^{16}$.

According to academician O. Bandurko prevention of offenses can be regarded as: 1) a system of collective and individual educational influences on the production of non-vulnerability, the formation of immunity to negative environmental influences in order to prevent the development of the personality orientation of the individual and realign the attitude of the individual to the reality in the process of re-education; 2) socially oriented organizational and legal activity of the state, its bodies and their officials, public organizations and individuals to identify the causes and conditions of committing crimes and offenses, eliminate the factors that contribute to the formation of antisocial behavior of a person, the elimination of offenses as a social phenomenon and restoration in the course of such activity of the rights and freedoms of Ukrainian citizens ${ }^{17}$.

That is, preventive activity is represented by a complex system with plurality of subjects of its implementation, which activities are united by a common purpose, but carried out by different methods that on different sides affect the reduction and destruction of factors that contribute to the origin of legal nihilism, the formation of antisocial behavior and lead to offenses, as well as common factors that contribute to the rise in crime (for example, mass unemployment; reduction of citizens' incomes; education; disadvantaged families; uncontrolled migration processes, etc.).

Particular importance for our study are scientific achievements of $\mathrm{V}$. Felika, obtained as a result of the investigation of the features of the prevention of offenses as one of the activities of the police, where the activity is proposed to be understood as "a system of police measures and powers, methods of their implementation, which are carried out with the purpose of preventing the commission of offenses or preventing or reducing their negative consequences., reducing the level of offenses in the state and in individual regions, ensuring a high level of public safety and order"18,

16 Клюєв О. М. Сутність та місце профілактичних заходів у правоохоронній діяльності. Право і суспільство. 2013. № 6. С. 195-197.

17 Бандурка О. М. Профілактика злочинності. Вісник Південного регіонального центру Начіональної академії правових наук України. 2014. № 1. С. 115-124.

18 Фелик В. І. Класифікація видів профілактичної діяльності Національної поліції України. Форум права. 2016. № 4. С. 313-316. URL: http://nbuv.gov.ua/jpdf/FP_index.htm_2016_4_51 (дата звернення: 15.10.2019). 
based on the following principles: priority of life, health, rights, freedoms and interests, honor and dignity of the individual and the citizen; democracy; personal freedom and privacy; equality of all citizens; the exclusivity and proportionality of the use of force by the police when taking preventive measures; honesty, impartiality and dignity; personal responsibility for the consequences of actions; legality; openness and transparency; political neutrality; partnerships with the public; continuity ${ }^{19}$.

That is, the prevention of offenses is a large-scale activity of subjects, where the police make a separate impact on the factors and conditions that lead to the commission of offenses, within the powers stipulated by the current legislation.

There is also no unanimous approach to the classification of prevention of offenses, and on the other hand, certain types of classifications are partially repeated by others. O. Dzhuzha and Y. Kondratyev distinguishes the following types of prevention: general, individual and early prevention of crimes - early detection and elimination of circumstances that in the future will affect the formation of deviant behavior of a person or group of people $^{20}$. In turn, academician O. Bandurka, focuses on emphasizes the expediency of classifying the prevention of offenses into general social and special, specifying that the latter consists of: "general special prevention; prevention of certain groups (types) of offenses; individual prevention; prevention of offenses" ${ }^{\prime 2}$.

More common in jurisprudence is the approach that identifies three types of prevention: general, special and individual ${ }^{22,23}$. More common in jurisprudence is the approach that distinguishes three types of prevention: general, special, and individual. Moreover, the contents of these species fully or partially coincide with the other types of prevention defined by us above (meaning general, special criminological and individual prevention).

Summarizing the above, we can state that the essence and content of preventive activity, as well as preventive activity, is a debatable question, the uncertainty of which determines the multiplicity of doctrinal views on its

19 Фелик В. І. Профілактика правопорушень як особливий напрям діяльності Національної поліції України. Прикарпатський юридичний вісник. 2015. Вип. 3. C. 229-232.

${ }^{20}$ Кримінологія : підручник / Джужа О. М. та ін.; за заг. ред. О. М. Джужи. Київ : Юрінком Інтер, 2002. 416 c.

21 Бандурка О. М. Профілактика злочинності. Вісник Південного регіонального центру Національної академії правових наук України. 2014. № 1. С. 115-124.

${ }_{22}^{22}$ Клюєв О. М. Сутність та місце профілактичних заходів у правоохоронній діяльності. Право і суспільство. 2013. № 6. С. 195-197.

23 Фелик В. І. Класифікація видів профілактичної діяльності Національної поліції України. Форум права. 2016. № 4. С. 313-316. URL: http://nbuv.gov.ua/j-pdf/FP_ index.htm_2016_4_51 (дата звернення: 15.10.2019). 
content, means and forms and requires specification, foremost in national law, and the adoption of a relevant legislative document that would not only identify important concepts for understanding prevention activities, and established a system of subjects and relationships between them during various preventive measures. In addition, the ambiguity of understanding of preventive activities complicates the understanding of another concept "preventive activity", during which preventive measures may take place. In this regard, the drafting and adoption of the Law of Ukraine "On Preventive Activities" is relevant.

However, it should be noted that, despite some doctrinal gaps, preventative activities have positive results, for example: optimization and increase of patrol routes in settlements in the area of the united forces operations; providing outreach, including the use of printing products and online resources; effective interaction with banking institutions led to a decrease in crimes such as robberies $(-28.6 \%)$, robberies $(-23 \%)$, unlawful seizure of vehicles $(-62 \%)$, fraud $(-21 \%)^{24}$.

In view of the above, we can identify following signs of preventive activity of the National Police: a) this is a set of measures, techniques and methods provided for by national law; b) carried out by police officers within the limits of their powers; c) is an independent line of police activity, at the same time becoming one of the activities within the system of preventive measures carried out by different state bodies; d) aimed at preventing an offense; e) has short and long term character; f) can have a mass and individual orientation; g) is being implemented within the limits specified by law; h) includes preventive police measures and, as a rule, preventive measures.

In view of this, we propose to define the concept of "preventive activity of the National Police" in a broad and narrow sense, depending on need to include in its component preventive measures in each case. Preventive activity of the police in the broadest sense implies the implementation of a system of actions and preventive measures, as well as techniques, methods and methods, carried out by authorized representatives of the National Police of Ukraine, with the aim of preventing, rarely - preventing, offenses that may be committed by people.

A narrow understanding of the preventive activity of the bodies of the National Police tends to legislatively determine its individual aspects of

\footnotetext{
${ }^{24}$ Колесник С. П. Проблемні питання забезпечення правопорядку в зоні проведення операції Об'єднаних сил. Забезпечення правопорядку на території проведення операиії Об'єднаних сил : матеріали Всеукр. наук.-практ. семінару, 12 жовт. 2018 р. Маріуполь : МДУ, 2018. С. 85-94.
} 
implementation it is a set of preventive police measures envisaged by legal acts that regulating the activities of police bodies, including administrative and criminal legislation, which are carried out by police officers within the limits of the powers conferred on them by law in order to prevent and prevent administrative offenses and crimes.

The application of specific methods, means, as well as directly police preventive measures depends on a number of conditions, which include: the geographical location of the territory, as well as the political and social situation within it; operational and criminogenic situation; crime rate; the number of police personnel, their level of professionalism, ability and skills; time allotted for this or that preventive process; the specific purpose for which they are pursued; categories of population living in the territory, etc. All these factors determine the specificity of the preventive activity of the police in each case. The first factor should be attributed to the special conditions for preventive action in the context of the anti-terrorist operation: it influences the definition of other conditions mentioned above and, in the aggregate, determines the specificity of the implementation of preventive activities.

\section{Implementation of preventive activities by the National police in the area of the united forces operations}

The protection of public order and security in the territory of conducting an anti-terrorist operation in the east of Ukraine from April 14, 2014 to April 30, 2018 was carried out in the specific areas of activity, which, due to the lack of necessity, are not implemented by police bodies of other areas:

- ensuring law and order during the rallies in 2014. Seizure of administrative buildings of the regional prosecutor's office, SSU, in Donetsk, the city council in Mariupol;

- carrying out according to military orders for the development of settlements of Donetsk region, including settlements located on the demarcation line;

- provision of public order after the shelling in the settlements of the Eastern neighborhood in Mariupol, Avdiivka, Marinka, Krasnogorovka, Granitne, Sartani, Hnutove, Mironovskii and others;

- provision of filtering measures at roadblocks;

- protection of public order during the blocking of railway tracks and highways;

- protection of objects of life and infrastructure of cities;

- protection of public order during large-scale events such as the concert "Ocean Elsa" in 2015, the Mariupol Fest in 2017 and 2018; 
- ensuring the protection of public order by the MMNP personnel, erected detachments in the settlements located on the demarcation line Svitlodarsk, Ocheretyne, Sopine, Hnutovo, Sartana, Mariinka, Krasnogorovka, Avdiivka;

- conducting general garrison briefings on the territory of Donetsk region, implementation of armor groups ${ }^{25}$.

In particular, the transformation of the socio-political situation and the need to recognize the armed aggression of the Russian Federation against Ukraine necessitated a change in the legal regime on the territory of Luhansk and Donetsk regions. As a consequence, based on the Declaration of State Sovereignty of Ukraine and the Constitution of Ukraine, underlining that Ukraine's sovereignty extends over its entire territory, which is holistic and inviolable within the internationally recognized state border, remaining committed to the course of political and diplomatic settlement of conflicts and principles of conflict of international law and the Charter of the United Nations, 18.01.2018 The Verkhovna Rada of Ukraine adopted the Law of Ukraine "On Features of State Policy for Ensuring State Sovereignty in Ukraine in the temporarily occupied territories in Donetsk and Luhansk regions" ${ }^{26}$. The aforementioned regulatory act envisages the peculiarities of the state policy of securing the state sovereignty of Ukraine in the temporarily occupied territories in Donetsk and Luhansk regions.

The result of the legislative innovations was the signing on 30.04.2018 of the Presidential Decree "On approving the decision of the National Security and Defense Council of Ukraine" On a large-scale anti-terrorist operation in the Donetsk and Luhansk regions", which enters into force the decision of the National Security and Defense Council on changing the format of a large-scale anti-terrorist operation the operation, which was launched in $2014^{27}$. The Head of State also signed an order of the Supreme Commanderin-Chief of the Armed Forces of Ukraine "On the commencement of the operation of the Joint Forces for the provision of national security and

25 Горустович Ю.В. Основні оперативно-профілактичні заходи, спрямовані на забезпечення правопорядку у донецькому регіоні в умовах ООС. Забезпечення правопорядку на території проведення операції Об'єднаних сил: матеріали Всеукр. наук.-практ. семінару, 12 жовт. 2018 р. Маріуполь : МДУ, 2018. С. 95-106.

${ }^{26}$ Про особливості державної політики із забезпечення державного суверенітету України на тимчасово окупованих територіях у Донецькій та Луганській областях : Закон України від 18 січн. 2018 р. № 2268-VIII. URL: https://zakon.rada.gov.ua/laws/main/2268-19 (дата звернення: 01.10.2018).

27 Про затвердження рішення Ради національної безпеки і оборони України від 30 квітня 2018 року "Про широкомасштабну антитерористичну операцію в Донецькій та Луганській областях": Указ Президента України від 30 квіт. 2018 p. URL: https://zakon.rada.gov.ua/laws/show/116/2018 (дата звернення: 15.10.2019). 
defense, repulsion and deterrence of the armed aggression of the Russian Federation in the territory of Donetsk and Luhansk regions", according to which, from 14:00 April 30, 2018, the Joint Forces of the National Security and Defense Forces, Repulsion and Suppression of the Armed Forces of the Russian Federation in Donetsk and Lugansk Oblast will be launched, in accordance with the plan of the said operation.

According to Art. 8 of the Law of Ukraine "On the Features of State Policy for Ensuring State Sovereignty of Ukraine in temporarily occupied territories in Donetsk and Luhansk Regions" 28 . The National Police are referred to the subjects of national security and defense, repelling and deterring armed aggression of the Russian Federation in Donetsk and Luhansk regions.

In turn, among law enforcement agencies, the police play a leading role in ensuring law enforcement in the area of the said operation. Such a conclusion directly follows, in particular, from the definition and tasks assigned to the police.

Thus, according to Art. 1 of the Law of Ukraine "On the National Police" The National Police of Ukraine is the central executive body which serves the society by ensuring the protection of human rights and freedoms, combating crime, maintaining public safety and order. In turn, in Art. 2 of the above legal act defines the tasks of the National Police as providing police services in the areas of: 1) ensuring public safety and order; 2) protection of human rights and freedoms, as well as the interests of society and the state; 3) combating crime; 4) providing services, within the limits specified by law, to persons who, for personal, economic, social or emergency situations, require such assistance ${ }^{29}$. We think that the formulation of police tasks as "providing police services" has become the basis of police activity, which is to serve the community.

Therefore, in our opinion, the role of the National Police as a subject of public security in the context of an anti-terrorist operation can be characterized on two levels. At the first (general) level, the role of the National Police in providing security for the joint operation, as well as for other security and defense sector bodies, is to ensure national security and defense, to repel and deter armed aggression in Donetsk and Luhansk regions.

28 Про особливості державної політики із забезпечення державного суверенітету України на тимчасово окупованих територіях у Донецькій та Луганській областях : Закон України від 18 січн. 2018 р. № 2268-VIII. URL: https://zakon.rada.gov.ua/laws/main/2268-19 (дата звернення: 01.10.2018).

${ }^{29}$ Про Національну поліцію : Закон України від 02 липн. 2015 р. № 580-VIII. URL: https://zakon.rada.gov.ua/laws/show/580-19 (дата звернення: 15.10.2019). 
In turn, the second level is manifested in the implementation of specific tasks that are assigned to the police as a new law enforcement agency in accordance with provisions of the Law of Ukraine "On National Police", the adoption of which was necessitated by the need to reform the police. In this context, police activities become special importance to preserve the life and health that not involved in national security and defense activities, and export to or from the area of operation of weapons, ammunition, explosives and narcotic substances, etc. ${ }^{30}$

In accordance with the provision of the Law of Ukraine "On Features of State Policy for Ensuring State Sovereignty of Ukraine in Temporarily Occupied Territories in Donetsk and Luhansk Oblasts", preventive measures in the conditions of the operation of the combined forces are carried out by the police on a wider spectrum than in other regions of Ukraine.

The General Staff of the Armed Forces of Ukraine, in agreement with the respective leaders, shall involve and use forces and means (personnel and specialists of individual units, military units, weapons, military equipment, special and transport vehicles, telecommunication and telecommunication facilities, other material and technical means) of The Armed Forces of Ukraine, other military units formed according to laws of Ukraine (the Security Service of Ukraine, the State Service for Special Communication and Information Protection of Ukraine, the National Guard of Ukraine, the State Border Service of Ukraine, the Office of the State Protection of Ukraine, the State Special Transport Service), law enforcement agencies of the special purpose, the Ministry of Internal Affairs of Ukraine, the National Police of Ukraine, the intelligence agencies of Ukraine, the military prosecutor's office, the central executive authority implementing the state policy in the sphere of civil protection, as well as employees of healthcare institutions (paragraph 1 of Part 1 of Article 8) ) $^{31}$.

At the same time, according to the norms of item 2 of part 1 of Art. 8 of the said legislative act, employees of the National Police are given special powers in implementing measures for the protection of public security, including preventive activities, which are inherently broader than those which provided in Section V of the Law of Ukraine "On the National

30 Аброськін В. В. Роль органів Національної поліції щодо забезпечення правопорядку в зоні проведення операції Об'єднаних сил. Забезпечення правопорядку на території проведення операції Об 'єднаних сил : матеріали Всеукр. наук.-практ. семінару, 12 жовт. 2018 р. Маріуполь : МДУ, 2018. С. 23-50.

31 Про особливості державної політики із забезпечення державного суверенітету України на тимчасово окупованих територіях у Донецькій та Луганській областях : Закон України від 18 січн. 2018 р. № 2268-VIII. URL: https://zakon.rada.gov.ua/laws/main/2268-19 (дата звернення: 01.10.2018). 
Police". The procedure and conditions for their application are defined in Art. 12 of the Law of Ukraine "On the Features of State Policy for Ensuring State Sovereignty of Ukraine in Temporarily Occupied Territories in Donetsk and Luhansk Regions".

In particular, police officers may not be guided by the grounds specified in the relevant articles of the Law of Ukraine "On the National Police" during the following preventive measures: verification of identification documents (and, in their absence, detention for the purpose of identification); personal inspection of persons and their belongings, including vehicles; restricting or prohibiting the movement of any vehicles and persons at all; restricting access to certain areas and objects (removal of citizens from that territory or object, towage of vehicles); entry or penetration into the territories, land plots and premises of residential and non-residential types belonging to natural and legal people under private ownership $^{32}$.

The above measures can be defined as preventive, which in a special order are authorized to apply police in the security zones adjacent to the territory of the fighting. Also, the police of that areas, where held the united forces operation, do preventive measures to identify and stop the activities of illegal armed groups and sabotage groups, prevent the supply of weapons, ammunition and narcotics, counteract terrorist acts and sabotage, facts of extremism, preventing the commission of serious crimes, the rights and freedoms of citizens. Thus, a number of preventative measures are directly aimed at preventing terrorism.

This indicates that the area of the united forces operations assumes the presence of a separate territory. For example, according to the experience of Ukraine we are talking about the territory of Donetsk and Luhansk regions, where, according to Part 2 of Art. 5 of the Law of Ukraine "On Combating Terrorism", the Ministry of Internal Affairs of Ukraine together with the National Police organizes the fight against terrorism by preventing, detecting and stopping crimes committed for terrorist purposes, the investigation of which is covered by the legislation of Ukraine within the competence of the National Police; provides the Anti-Terrorist Center with the Security Service of Ukraine with the necessary resources and resources; ensures their effective use in counter-terrorism operations ${ }^{33}$.

32 Про Національну поліцію : Закон України від 02 липн. 2015 р. № 580-VIII. URL: https://zakon.rada.gov.ua/laws/show/580-19 (дата звернення: 15.10.2019).

${ }^{33}$ Про боротьбу з тероризмом : Закон України від 20 бер. 2003 р. № 638-15. URL: https://zakon.rada.gov.ua/laws/show/638-15 (дата звернення: 15.10.2019). 
In accordance with the Law of Ukraine "On the Fight against Terrorism" special and special purpose units were given the right to prevent the detention of people who involved in terrorist activities for more than 72 hours (the maximum period of preventive detention may not exceed 30 days).

The reason for the preventive detention is the existence of reasonable suspicion of committing a terrorist activity. Preventive detention is carried out by a reasoned decision of the Chief of the Main Directorate of the Security Service of Ukraine or the Chief of the Main Directorate of the Ministry of Internal Affairs of Ukraine in the Autonomous Republic of Crimea, in the respective area, in Kyiv and Sevastopol with the consent of the prosecutor and without the decision of the investigating judge, court. A copy of the decision on the preventive detention of a person who involved in terrorist activity shall be promptly forwarded to the detained person for a period of more than 72 hours and shall be immediately forwarded to the investigating judge, the court of the respective jurisdiction, together with the request for the election of the appropriate preventive measure against the person.

Preventive detention of a person may not continue after consideration by an investigating judge, a court requesting the election of an appropriate preventive measure against that person.

It should also be added that the Law "On the Fight against Terrorism" provides for the introduction of a special regime in the area of the united forces operations, according to which the subjects of the fight against terrorism have the special powers required by law for the release of hostages, security and health. citizens who were in the area of the operation of the United Forces, normal functioning of state bodies, local self-government bodies, enterprises, institutions, organizations.

The current legislation, namely item 7 of the Regulation on a unified state system of prevention, response and termination of terrorist acts and minimization of their consequences, established levels of terrorist threats:

"GRAY (possible threat)" - in the presence of factors contributing to the commission of a terrorist act;

"BLUE (potential threat)" - in the presence of information requiring confirmation about the preparation for the commission of a terrorist act;

"YELLOW (probable threat)" - in the presence of reliable and confirmed information about the preparation for committing a terrorist act;

"RED (real threat)" - in the case of a terrorist act.

Along with these levels, special security regimes have been established to determine the conditions of stay of citizens and the special powers of the National Police in the area of the united forces operations. Generally, it is 
possible to establish three modes: green, which does not restrict the stay of persons in a certain area; yellow, which is set for restricted areas; red, which is for restricted areas (facilities), the same mode is set in combat areas.

The level of specific powers of the National Police officers and the list of specific preventive measures that they can apply in the context of a joint operation depend on the establishment of a particular level. Thus, the general list of preventive measures defined in Art. 12 of the Law of Ukraine "On features of state policy on securing state sovereignty of Ukraine in temporarily occupied territories in Donetsk and Luhansk regions" 34 , it is not permanent, and it is subject to differentiation depending on the identified threat level.

It should also be emphasized that such preventive measures which are authorized by the police and their general list, which is defined in the legislation, are not exhaustive and may be changed by the Chief of General Staff - Commander-in-Chief of the Armed Forces of Ukraine upon submission by the Joint Force Commander in case of special order conditions, in particular:

1) threats of using lesions, including rocket troops and artillery, rocket launcher systems and aviation;

2) threats of terrorism and sabotage acts, which means, "committing for the purpose of weakening the state explosions, arson or other actions aimed at mass destruction of people, causing bodily harm or other harm to their health, the destruction or damage of objects that have important national economic or defense value, as well as committing for the same purpose actions aimed at radioactive contamination, mass poisoning, spread of epidemics, epizootics or epiphytoties (Article 113 of the Criminal Code of Ukraine);

3) movements of military columns; conducting activities to search for and destroy sabotage forces or enemy groups; land mine clearance measures; conducting combat and operational trainings;

4) providing with the operational search works; occurrence of the natural and man-made emergencies;

5) verification of readiness of forces and means to fulfill tasks on purpose;

6) ensuring security for the top military-political leadership of the state and representatives of the partner countries.

34 Про особливості державної політики із забезпечення державного суверенітету України на тимчасово окупованих територіях у Донецькій та Луганській областях : Закон України від 18 січн. 2018 р. № 2268-VIII. URL: https://zakon.rada.gov.ua/laws/main/2268-19 (дата звернення: 01.10.2018). 
All what is mentioned above gives reasons to distinguish the following features of the preventive actions of the police in the conditions of a joint operation:

1) mainly concerns preventive activities, i.e. specific preventive measures implemented by police officers, who are conditioned by the peculiarities of conducting a joint force operation, which requires rapid management decisions and operational measures. The implementation of prevention, which is part of the prevention actions of the police, takes some time to obtain the results of its' implementation;

2) is a set of measures, techniques and methods provided in a special legislative act that defines the conditions of public policy, particularly in the field of law enforcement, in the conditions of the operation of the joint forces;

3) the police carry out preventive measures aimed to prevent the activities of illegal armed groups and subversive groups, preventing the supply of weapons, ammunition and drugs, counteracting terrorist acts and sabotage, extremism, whereas the last one is the most characteristic for the territory of the Joint Force operation;

4) there are extended grounds for application and a list of preventive police measures;

5) determination of specific preventive measures that can be applied by the National Police depending on the occurrence of special order conditions commands the Chief of General Staff;

6) specifics of the application of certain preventive measures, as well as the extent of police powers, depend on the establishment of a special regime in the area of the united forces operations ${ }^{35}$.

The existence of specially designated areas covered by the special status and regime whereby law enforcement agencies acquire special powers, as well as the high potential level of danger during the united forces operations, necessitate continuous systematic monitoring. The state of law and order in which the operation of the joint forces is carried out depends to some extent on the quality of preventive activity by the national police.

\section{CONCLUSIONS}

Preventive activity of the police provides the implementation of a system of actions and preventive measures, as well as techniques, methods and

35 Аброськін В. В. Роль органів Національної поліції щодо забезпечення правопорядку в зоні проведення операції Об'єднаних сил. Забезпечення правопорядку на території проведення операції Об 'єднаних сил : матеріали Всеукр. наук.-практ. семінару, 12 жовт. 2018 р. Маріуполь : МДУ, 2018. С. 23-50. 
methods, carried out by authorized representatives of the police, to prevent offenses that may be committed by person or groups of people.

The use of police preventive measures during the united forces operations depends on a number of conditions, which are proposed to include: the geographical location of the territory, as well as the political and social situation within it; operational and criminogenic situation; crime rate; the number of police personnel, their level of professionalism, ability and skills; time allotted for this or that preventive process; the specific purpose for which they are pursued; categories of population living in the territory, etc.

It is established that preventive measures in the context of the united forces operations in individual regions are carried out by the police on a wider spectrum. In addition, police officers are empowered to implement public safety measures, including preventive activities, which are inherently broader than those provided for in Section V of the Law "On National Police".

\section{SUMMARY}

The article is devoted to the research of preventive activity of the National Police in the area of the united forces operations. Theoretical approaches to the definition and correlation of the concepts of "termination", "prevention" are investigated. The peculiarities of preventive activities carried out by the Ukrainian police in the context of the united forces operations have been clarified. The content of "preventive activity" is disclosed. The signs of preventive activity of the police are formulated. The classification of the prevention of offenses is made.

It is established that preventive measures in the context of the united forces operation in individual regions are carried out by the police on a wider spectrum. It is proved that police officers are vested with special powers during the implementation of measures of public security, including preventive activities, that are substantially broader than those, which provided for by section V of the Law of Ukraine "On the National Police".

\section{REFERENCES}

1. Конституція України : Закон України від 28 черв. 1996 p. № 254к/96-BP. URL: http://zakon.rada.gov.ua/laws/show/254к/96-BP (дата звернення: 03.10.2019).

2. Про боротьбу з тероризмом : Закон України від 20 бер. 2003 р. № 638-15. URL: https://zakon.rada.gov.ua/laws/show/638-15 (дата звернення: 15.10 .2019$)$. 
3. Про Національну поліцію : Закон України від 02 липн. 2015 р. № 580-VIII. URL: https://zakon.rada.gov.ua/laws/show/580-19 (дата звернення: 15.10.2019).

4. Про особливості державної політики із забезпечення державного суверенітету України на тимчасово окупованих територіях у Донецькій та Луганській областях : Закон України від 18 січн. 2018 р. № 2268VIII. URL: https://zakon.rada.gov.ua/laws/main/2268-19 (дата звернення: 01.10.2018).

5. Про затвердження рішення Ради національної безпеки і оборони України від 30 квітня 2018 року "Про широкомасштабну антитерористичну операцію в Донецькій та Луганській областях" : Указ Президента України від 30 квіт. 2018 p. URL: https://zakon.rada.gov.ua/ laws/show/116/2018 (дата звернення: 15.10.2019).

6. Про Стратегію сталого розвитку "Україна - 2020" : Указ Президента України від 12 січ. 2015 р. № 5/2015. URL: http://zakon2.rada.gov.ua/laws/show/5/2015 (дата звернення 15.10.2019).

7. Аброськін В. В. Роль органів Національної поліції щодо забезпечення правопорядку в зоні проведення операції Об'єднаних сил. Забезпечення правопорядку на території проведення операиіï Об'єднаних сил : матеріали Всеукр. наук.-практ. семінару, 12 жовт. 2018 р. Маріуполь : МДУ, 2018. С. 23-50.

8. Адміністративні правопорушення: демографічна та соціальна статистика. Правосуддя та злочинність. Державна служба статистика Украӥни : веб-сайт. URL: http://www.ukrstat.gov.ua (дата звернення: 15.10.2019).

9. Бандурка О. М. Профілактика злочинності. Вісник Південного регіонального иентру Національної академії правових наук Украӥни. 2014. № 1. C. 115-124.

10. Батраченко О. В. Форми правоохоронної діяльності національної поліції щодо забезпечення публічної безпеки та порядку в державі. Форум права. 2016. № 2. C. 5-10. URL: http://nbuv.gov.ua/j-pdf/FP_ index.htm_2016_2_3. (дата звернення: 15.10.2019).

11. Валєєв Р. Г., Чуріков Д. С. Превентивна діяльність поліцейських як стадія протидії злочинності. Актуальні питання протидї злочинності в сучасних умовах: вітчизняний та зарубіжний досвід : матеріали II Міжнар. наук.-практ. конф., 15 бер. 2013 р. Дніпро : Дніпропетр. держ. ун-т внутр. справ, 2018. С. 212-215.

12. Василенко В. А. Російсько-українська війна 2014 року: причини, перебіг та політико-правові оцінки. Украӥнський тиждень. 2014. № 42. C. $28-42$. 
13. Волокітенко I. О. Адміністративно-правовий статус підрозділів превентивної діяльності Національної поліції України. Visegrad Journalon Human Rights. 2016. № 6. Ч. 2. C. 42-46.

14. Горустович Ю. В. Основні оперативно-профілактичні заходи, спрямовані на забезпечення правопорядку у донецькому регіоні в умовах ООС. Забезпечення правопорядку на території проведення операції Об'єднаних сил : матеріали Всеукр. наук.-практ. семінару, жовт. 2018 р. Маріуполь : МДУ, 2018. С. 95-106.

15. Дідик Н. І. Превентивні функції в діяльності патрульної поліції. Вісник Луганського державного університету внутрішніх справ імені Е. О. Дідоренка. 2016. Вип. 2. С. 188-194.

16. Клюєв О. М. Сутність та місце профілактичних заходів у правоохоронній діяльності. Право і суспільство. 2013. № 6. С. 195-197.

17. Клюєв О. М. Форми та методи профілактичної діяльності органів внутрішніх справ на місцевому рівні. Форум права. 2007. № 1. C. 99-103. URL: http://nbuv.gov.ua/j-pdf/FP_index.htm_2007_1_19 (дата звернення: 15.10.2019).

18. Колесник С. П. Проблемні питання забезпечення правопорядку в зоні проведення операції Об'єднаних сил. Забезпечення правопорядку на території проведення операщії Об'єднаних сил : матеріали Всеукр. наук.-практ. семінару, 12 жовт. 2018 р. Маріуполь : МДУ, 2018. С. 85-94.

19. Кримінологія : підручник / Джужа О.М. та ін.; за заг. ред. О. М. Джужи. Київ : Юрінком Інтер, 2002. 416 с.

20. Макаренко О. М. Суб'єкти профілактики правопорушень. Право і Безпека. 2004. № 3 (3). С. 68-70.

21. Словник української мови : в 11 т. / голова редкол. І. К. Білодід. Київ : Наукова думка, 1976. Т. 7. 724 с.

22. Фелик В. І. Класифікація видів профілактичної діяльності Національної поліції України. Форум права. 2016. № 4. С. 313-316. URL: http://nbuv.gov.ua/j-pdf/FP_index.htm_2016_4_51 (дата звернення: 15.10.2019).

23. Фелик В. І. Профілактика правопорушень як особливий напрям діяльності Національної поліції України. Прикарпатський юридичний вісник. 2015. Вип. 3. С. 229-232.

Information about the author: Abroskin V. V., Doctor of Law, Rector, Odesa State University of Internal Affairs 1, Uspenska str., Odessa, 65000, Ukraine 